\title{
Volatility Spillover Effect in Indian Stock Market
}

Surya Bahadur G. C.

Assistant Professor, School of Business, Pokhara University, Nepal

Email: suryagc@gmail.com

Ranjana Kothari

Assistant Professor, Amity University, Gurgaon, India

\section{Rajesh Kumar Thagurathi}

Associate Professor, Faculty of Management, Pokhara University

\section{Abstract}

The study aims to empirically examine the transmission of volatility from global stock markets to Indian stock market. The study is based on time series data comprising of daily closing stock market indices from National Stock Exchange (NSE), India and major foreign stock exchange of the three countries one each from America, Europe and Asia making the highest portfolio investment in Indian stock market. The study period covers 11 years from $1^{\text {st }}$ January, 2005 to $31^{\text {st }}$ December, 2015 comprising a total of 2731 observations. The Indian stock index used is CNX Nifty 50 and the foreign indices are S \& P 500 from USA, FTSE 100 from UK, and Nikkei 225 from Japan. The results reveal that the Indian stock market return is co-integrated with market returns of US, UK and Japanese stock markets. Therefore, the return and hence volatility of Indian stock market is associated with global markets which depicts that it is getting integrated with global financial markets. The results provide empirical evidence for volatility transmission or volatility spillover in the Indian stock market from global markets. There exists inbound volatility transmission from US market to Indian stock market. The Indian and UK stock market have bi-directional volatility transmission. However, there exists presence of only outbound volatility transmission from Indian stock market to Japanese stock market. The volatility transmission from global markets to India is rapid with the spillover effect existing for up to three days only.

Keywords: Contagion, financial integration, Indian stock market, volatility spillover, volatility transmission. 


\section{Introduction}

Stock prices volatility has received great attention from both academics and practitioners over the last two decades because it is a measure of risk in financial markets. Over recent years, there has been a growth in interest in the study of stock market volatility. The phenomenon of volatility spillover refers to the transmission or contagion of stock market shocks across a country or regions. Internationalization of stock markets, liberalized capital flows, huge foreign portfolio investment in Indian stock markets has led Indian and foreign stock markets to be increasingly integrated. In addition to various domestic factors, volatility of major foreign trading partners is one of the important determinants of stock return volatility in a domestic market (Mukherjee, 2005). An understanding of the inter-market volatility transmission is important for the portfolio diversification and asset allocation across the markets, for trading and devising hedging strategies. Indian stock market has emerged as one of the favorite destination of Foreign Institutional Investments (FIIs). In particular, deregulation and market liberalization measures, rapid development in communication technology and computerized trading systems, and increasing activities of multinational corporations have accelerated the growth of Indian capital market, which is now slowly moving towards global financial integration (Kumar and Mukhopadhyay, 2002). In order to understand volatility of Indian stock markets, study of volatility spillover is also required.

The empirical literature on volatility spillover effect concentrates mostly on well-developed equity markets in the US, Japan and Europe. Wang (2005) have examined the return and volatility spillover from US and Japan to three Asian capital market viz. India, Pakistan and Sri Lanka. Though they have found a return spillover from US and Japan to all the three markets, there is a significant volatility spillover from US to India and Sri Lanka and from Japan to Pakistan. Bhar and Nikolova (2007) analyze the degree of integration of the BRIC countries on a regional and global basis, achieved by using daily equity index level data. The paper concludes that a high degree of integration exists between the BRIC countries and their respective regions, 
and to a lesser extent, the rest of the world. Similarly, Lee (2009) conducted study on volatility spillover in Asian markets and found that there are statistically significant volatility spillover effects within the stock markets of these countries. Wang and Shih (2010) investigate the dynamic nature and determinants of volatility spillovers from European region and world to the five emerging European equity markets that are not members of the European Monetary Union. Their results show significant world and regional effects on volatility. Azzam (2010) provide evidence of asymmetric market responses to shocks in all markets. The effects of negative shocks are much more pronounced than positive shocks. Li and Giles (2013) examine the linkages of stock markets across the U.S., Japan and Asian developing countries over the period January 1, 1993 to December 31, 2012. The study finds significant unidirectional shock and volatility spillovers from the U. S. market to both the Japanese and the Asian emerging markets. Further, in recent periods the linkages between the Japanese market and the Asian emerging markets have become more apparent.

Few prior studies on volatility spillover in India exist. Rao and Naik (1990) examined linkages between developed markets and Indian stock market before liberalization and concluded that the Indian market is not integrated with global stock markets. Given the present state of Indian stock markets, these studies lose their relevance. With active liberalization and rapid growth of information technology in the recent past, (Kumar and Mukhopadhyay, 2002) have examined the response of the Indian Stock Market to world markets viz., US, Japan and other East Asian Stock Markets. They find evidence of volatility spillover from US to Indian stock market. Similarly, by carrying a comprehensive analysis from correlation to Granger causality and then to application of GARCH models to examine the comovement and volatility transmission between US and Indian stock markets, Kumar (2012) have found significant return and volatility spillover from US to India. The review of extant literature on volatility transmission reveals that most prior studies are undertaken on context of developed markets. Given the growth of stock market of emerging nations and growing integration 
with global tinancial markets in recent periods, more studies tocusing in the markets are essential. Hence, the study aims to investigate the volatility transmission from major American, European and Asian markets to India.

\section{Financial Integration and Volatility Transmission}

The recent decade is characterized by strong evolution of financial markets and financial globalization. Globalization and financial markets have now become so closely linked that they seem inseparable. On the one hand, capital movements intensify cross-border each year more, while on the other hand, national economies are more and more open to foreign capital flows. The internationalization of financial markets is the result of double phenomena. First, the accelerated deregulation of national money and financial markets, and second, the direct national markets interconnection, particularly by the formation of large external capital markets like Euromarkets (Achert and Deaver, 2010). In terms of economic efficiency, the integration of international financial markets leads to better allocation of productive resources and capital. Caprio (2012) argue that although, it promotes economic efficiency and financial strength, international financial integration has some drawbacks. The volatility and instability of financial markets are the major disadvantages of financial integration. The relationship between financial integration and volatility is complex. It depends on the stage of development of the markets. As financial integration is usually accompanied by an increasing openness of markets and increased private capital flows, it coincides in most of the time with an excess of volatility and a strong dependence on other countries $(\mathrm{Ng}, 2000$; Karmakar, 2007).

According to Yang et al. (2012), the last two to three decades have witnessed increasing levels of financial integration among the world economies, as restrictions on capital mobility across countries have gradually weakened. The consequential increase in cross-border financial flows, along with the increasing regionalization of economic activity, has resulted in greater interdependence of major financial markets all over the world. The world financial markets have experienced increasing integration, resulting in 
transmission of financial shocks across connected markets. While this is not a surprising outcome of economic and financial integration, the dynamics, the mode, and channels of contagion and shock transmission continue to be subjects of interest and investigation (Caprio, 2012). Researchers have gone to great lengths to investigate the channels of contagion, shock transmission, and volatility spillovers among world major markets, in emerging markets, and between them. There are some obvious ramifications of the findings of such research. For instance, evidence of volatility spillovers and dynamics would offer an understanding on the degree of openness and economic co-dependence of global economies (Badhani, 2009). As a result of such linkages, news released in one country may affect not only local market returns, but the returns of foreign markets as well. The newly arrived information may be reflected either instantly in the foreign market returns, or with a lag, depending on informational asymmetries, market liquidity and other local market factors. The more financially open a stock market is, the more synchronized its returns are with the returns of foreign markets, and the greater the scope for return spillovers ((Arouri and Nguyen, 2009; Caprio, 2012).

During the past two decades, the contagious effect of financial crises has been of great concern because of its important consequences for the global economy in relation to optimal asset allocation and monetary policy (Welfens and Ryan, 2011). The volatility spillover effect observed after the recent global financial crisis of 2008 and Eurozone sovereign debt crisis has made this issue more prominent. National and international regulators and central bankers need information and insight into these issues in order to be able to cope with spillovers of volatility, especially during the periods of financial crises. In particular, world's central bankers and other financial policy makers would benefit from this line of research findings may become better equipped to cope with contagious effects of shocks among markets (Harrison and Moore, 2009).

\section{Data and Methods}


The study is based on time series data of comprising of daily closing stock market indices from National Stock Exchange (NSE), India and major foreign stock exchange of the three countries one each from America, Europe and Asia making the highest portfolio investment in Indian stock market from $1^{\text {st }}$ January, 2005 to $31^{\text {st }}$ December, 2015 covering a period of 11 years comprising a total of 2731 observations. The time period covers periods of relatively greater volatility in Indian stock market. The Indian stock market index used is CNX Nifty 50 NSE. The exchange is selected as it has the highest turnover and number of trades in equity and derivatives segment in India. The Nifty 50 is blue chip index of NSE which is most popular and widely used stock market indicator of the country. It consists of diversified 50 stocks index accounting for 22 sectors of the economy. Nifty 50 accounts for about $65 \%$ percent of total market capitalization of capital market segment of NSE as on December, $30^{\text {th }}$ 2015. The foreign indices are S \& P 500 from USA, FTSE 100 from UK, and Nikkei 225 from Japan which are the benchmark indices. The data of stock indices series used in the study are collected from the databases of the respective stock exchanges publicly available in their official websites.

The daily market returns $\left(R_{t}\right)$ are calculated as the logarithmic first differences of the stock market indices. The reasons to take logarithm returns are justified both theoretically and empirically. Theoretically, logarithmic returns are analytically more tractable when linking returns over longer intervals. Empirically, logarithmic returns are more likely to be normally distributed which is a prior condition of standard statistical techniques. Market return is a simple measure of fluctuations in stock prices. Higher the fluctuations, higher are the market returns and volatility. The daily market returns of the stock market indices used in the study is computed as logarithmic difference as follows:

$$
R_{t}=\log \left[\frac{I_{t}}{t_{t-1}}\right] \times 100
$$

Where, $R_{t}$ is return in time $t . I_{t}$ is the value of stock market index in time $t$ and $\mathrm{I}_{\mathrm{t}-1}$ is one period lagged value of stock market index. 


\section{Model Specification}

This study investigates the volatility spillover from foreign stock market to India employing different time series econometric models. The estimation of the models is undertaken employing econometric package Eviews 7.0. The time series models are discussed below:

\section{Unit Root Test}

The stock market indices series that are used in this study may possess unit roots as indicated by the substantial evidence in literature in time series analysis. Since, the presence of non-stationary variables in the estimation process may yield spurious result, the study begins with the unit root test for the variables under study using Augmented Dickey Fuller (ADF) test. The study tests all market indices for presence of unit root in their levels and in their first difference form. The popular ADF unit root test of the null hypothesis of non-stationary is expressed as:

$$
\Delta R_{k t}=\alpha_{0}+\alpha_{1} t+\rho_{0} R_{k t-1}+\sum_{k=1}^{q} \rho_{i} \Delta R_{k t-k}+\varepsilon_{k t}
$$

Where, $R_{k t}$ denotes the return for the $k^{\text {th }}$ market index at time $t$ and $\Delta R_{k t}=$ $\rho$

$R_{k t}-R_{k t-1}$ are coefficients to be estimated, $q$ is the number of lagged terms, $t$ is the trend term, $\alpha_{1}$ is the estimated coefficient for the trend, $\alpha_{0}$ is the constant, and $\varepsilon$ is white noise. MacKinnon's critical values are used in order to determine the significance of the test statistic associated with $\rho_{0}$. The unit root tests the null hypothesis $\mathrm{H}_{0}: \rho=1$ against the one-sided alternative $\mathrm{H}_{1}: \stackrel{\rho}{<}<1$. The null hypothesis of a unit root is rejected in favor of the stationary alternative in each case if the test statistic is more negative than the critical value.

\section{Cointegration Test}

The cointegration test could be used to discover the existence of the long-run relationship between the Indian and foreign stock market returns volatility. Many financial time series are non-stationary but "move together 
over time" (i.e., there exist some influences on the series, which imply that the two series are bound by some relationship in the long run). If the result in unit root test shows that two or more time series are non-stationary in their levels but integrated of the same order, the cointegration test would be conducted to test whether their linear combination is stationary at $I(0)$ implying that they are cointegrated. The two or more time series are said to be cointegrated when the residual of their cointegrating regression is stationary. Statistically, the long-term relationship implies that the variables move together in the long-run, therefore the short-run deviations from the trend in long-run would be corrected (Dickey, Jansen, and Thornton, 1991).

The Engle and Granger (1987) proposed the single equation based method by the two-step procedure in order to model the relationship between cointegrated variables. First, estimating the long-run relationship cointegrating regression by OLS regression:

$$
R_{d t}=\beta_{1}+\beta_{2} R_{f t}+\varepsilon_{t}
$$

Where, $R_{d}{ }^{t}$ and $R_{f}^{t}$ represent the time series of domestic and foreign stock market returns respectively and ${ }^{\varepsilon_{t}}$ represent the residuals. Second, retaining the residuals from cointegrating regression in first step:

$$
\varepsilon_{t}=R_{d t}-\beta_{1}-\beta_{2} R_{f t}
$$

Then applying the ADF tests to these residuals as in the equation below:

$$
\Delta \hat{\varepsilon}_{t}=\gamma \hat{\varepsilon}_{t-1}+\sum_{i=1}^{p} \alpha_{i} \Delta \hat{\varepsilon}_{t-1}+u_{t}
$$

The ${ }^{\hat{\varepsilon}_{t}}$ values are estimated residuals. The test statistic is the estimated ' $\mathrm{t}$ ' statistic on $\gamma$, denoted by ${ }^{\hat{\tau}_{y}}$. The null hypothesis, $\mathrm{H}_{0}: \gamma=0$, i.e. the two time series are non-cointegrating. If the null hypothesis is rejected, it means that domestic market returns $\left(R_{d t}\right)$ and foreign market returns $\left(R_{f t}\right)$ are 
cointegrated and the residual ${ }^{\varepsilon_{t}}$ is a I(0) process or stationary. On the other hand, if $R_{\mathrm{dt}}$ and $\mathrm{R}_{\mathrm{ft}}$ are not cointegrated, the residual ${ }^{\varepsilon_{t}}$ is a unit root process (non-stationary).

\section{Granger's Causality Test}

The Granger's causality test is also be employed analyze volatility spillover effect from global stock markets to Indian stock market. The model is specified as two equation system given below:

$$
\begin{aligned}
\Delta \mathrm{R}_{\mathrm{dt}} & =\alpha_{0}+\sum_{i=1}^{k} \alpha_{i} \Delta \mathrm{R}_{\mathrm{d}, \mathrm{t}-\mathrm{i}}+\sum_{i=1}^{k} \beta_{i} \Delta \mathrm{R}_{\mathrm{f}, \mathrm{t}-\mathrm{i}}+\delta_{1} \mathrm{ECT}_{\mathrm{t}-1}+\varepsilon_{\mathrm{t}} \\
\Delta \mathrm{R}_{\mathrm{ft}} & =\gamma_{0^{+}}+\sum_{i=1}^{k} \gamma_{i} \Delta \mathrm{R}_{\mathrm{f}, \mathrm{t}-\mathrm{t}}+\sum_{i=1}^{k} \theta_{i} \Delta \mathrm{R}_{\mathrm{d}, \mathrm{t}-\mathrm{i}}+\delta_{2} \mathrm{ECT}_{\mathrm{t}-1}+v_{\mathrm{t}}
\end{aligned}
$$

Where, $R_{d t}$ is domestic stock market index, ECT is error correction term, $R_{\mathrm{ft}}$ is foreign stock market index, $i$ is a positive integer, $i=0,1, \ldots \ldots, k, \Delta$ is the first difference operator and $\varepsilon_{\mathrm{t}}$ and $v_{\mathrm{t}}$ are white noise residual that follows the stationary process when two variables are integrated of order one. $\mathrm{ECT}_{\mathrm{t}-1 \mathrm{~S}}$ are the lagged residuals obtained from the long-run cointegrating relationship between the $R_{\mathrm{dt}}$ and $\mathrm{R}_{\mathrm{ft}}$ and $\delta_{1}$ and $\delta_{2}$ denote speeds of adjustment. Existence of the cointegration indicates causality among a set of financial variables. Accepting the null hypothesis Ho: $\beta_{1}=\beta_{2}=\ldots \ldots=\beta_{k}=0$ and $\delta_{1}=0$, indicates that the change in stock market volatility in foreign stock market $\left(R_{\mathrm{ft}}\right)$ does not 'Granger cause' Indian stock market volatility $\left(R_{d t}\right)$ and accepting the null hypothesis Ho: $\theta_{1}=\theta_{2}=\ldots \ldots=\theta_{k}=0$ and $\delta_{2}=0$, indicates that changes in domestic stock market volatility not 'Granger cause' volatility in foreign stock market. However, if $R_{\mathrm{dt}}$ and $\mathrm{R}_{\mathrm{ft}}$ are not cointegrated, then the error correction term would be absent from the above equations.

\section{ARDL Model}

Finally, Autoregressive distributed lag (ADRL) model is employed to examine the volatility transmission between the Indian and foreign stock markets. 
The ADRL contains lagged values of the dependent and independent variables. The model has been specified as given below:

$$
\mathrm{R}_{\mathrm{d}, \mathrm{t}}=\alpha_{0}+\sum_{i=1}^{k} \alpha_{i} \sum_{\mathrm{d}, \mathrm{t}-\mathrm{i}}+\sum_{i=1}^{k} \beta_{i} \mathrm{R}_{\mathrm{f}, \mathrm{t}-\mathrm{i}}+\varepsilon_{\mathrm{t}}
$$

The number of lags (k) used is 1 to 5 days.

\section{Results and Discussion}

Table I exhibits the results of the Augmented Dickey Fuller (ADF) unit root test. In case of ADF, the null hypothesis of a unit root (non-stationarity) is tested against the alternative of no unit root (stationarity). The unit root test rejects the null hypothesis if the ADF test statistics value in absolute form is higher than the MacKinnon critical values given in the last section of the following table. Most time series models used in later sections require that the data series to be stationary in order to avoid problem of spurious relationship. The stationarity test is applied both in level and first differenced values.

\section{Table 1}

Test of Stationarity in Stock Market Indices: Output of Unit Root Test

\begin{tabular}{|c|c|c|c|c|c|}
\hline & \multicolumn{4}{|c|}{ ADF Test Statistics } & \multirow{2}{*}{$\begin{array}{c}\text { Integration } \\
\text { order }\end{array}$} \\
\hline & Level & Result & $\begin{array}{c}1^{\text {st }} \\
\text { Differenc } \\
e\end{array}$ & Result & \\
\hline \multicolumn{6}{|c|}{ Indian Indices } \\
\hline NIFTY 50 & $\begin{array}{l}- \\
1.22602 \\
0\end{array}$ & Unit Root & -48.73632 & $\begin{array}{l}\text { Stationar } \\
\mathrm{y}\end{array}$ & $\mathrm{I}(1)$ \\
\hline BSE Sensex & $\begin{array}{l}- \\
1.33078 \\
4\end{array}$ & Unit Root & -48.28141 & $\begin{array}{l}\text { Stationar } \\
\mathrm{y}\end{array}$ & $\mathrm{I}(1)$ \\
\hline \multicolumn{6}{|c|}{ Foreign Stock Market Indices } \\
\hline S\&P500 & $\begin{array}{l}- \\
0.40603\end{array}$ & Unit Root & -57.64926 & $\begin{array}{l}\text { Stationar } \\
y\end{array}$ & $\mathrm{I}(1)$ \\
\hline
\end{tabular}




\begin{tabular}{|c|c|c|c|c|c|}
\hline & 5 & & & & \\
\hline FTSE100 & $\begin{array}{l}- \\
2.53076 \\
9\end{array}$ & Unit Root & -39.81476 & $\begin{array}{l}\text { Stationar } \\
\mathrm{y}\end{array}$ & $\mathrm{I}(1)$ \\
\hline NIKKEI225 & $\begin{array}{l}- \\
0.94114 \\
8\end{array}$ & Unit Root & -53.22747 & $\begin{array}{l}\text { Stationar } \\
\mathrm{y}\end{array}$ & $\mathrm{I}(1)$ \\
\hline \multicolumn{6}{|c|}{ MacKinnon critical values for rejection of hypothesis of a unit root: } \\
\hline & \multicolumn{2}{|c|}{$1 \%$} & \multicolumn{2}{|c|}{ Critical Value } & -3.4382 \\
\hline & \multicolumn{2}{|c|}{$2 \%$} & \multicolumn{2}{|c|}{ Critical Value } & -2.8642 \\
\hline & \multicolumn{2}{|c|}{$3 \%$} & \multicolumn{2}{|c|}{ Critical Value } & -2.5682 \\
\hline
\end{tabular}

The results in the Table I show that all the markets indices both domestic and foreign are non-stationary in level form. The ADF test statistics in absolute form for the series is not greater than the critical values, hence the null hypothesis of presence of unit root is accepted. Hence, the market return series contain unit-root and are non-stationary. First differencing time series data is a method to remove unit root form the series. Hence, all the non-stationary indices series are first differenced and unit root test applied again. The ADF test statistics of all the first differenced return series are larger than the critical values, and hence the series are found to be stationary in first differenced form. So, all the series are found to be integrated in order of one as first differencing them once converts the nonstationary series to stationary.

Table II presents output of the co-integration test to investigate the presence of long term equilibrium relationship between returns of major global stock market's return with Nifty 50 returns. The co-integration of Indian market is examined with three foreign global stock markets of the countries that have largest foreign portfolio investment in Indian stock market, viz., USA, UK and Japan. The foreign market index used are S\&P 500, FTSE 100, and Nikkei 225 for USA, UK and Japanese stock market respectively. Moreover, the stock indices are representative of American, European and Asian markets. 


\section{Table 2}

Results of Co-integration Test

\begin{tabular}{|c|c|c|c|c|c|}
\hline Pair & $\begin{array}{c}\text { Hypothesized } \\
\text { No. of CE(s) }\end{array}$ & $\begin{array}{l}\text { Eigen } \\
\text { Value }\end{array}$ & $\begin{array}{c}\text { Trace } \\
\text { Statistic }\end{array}$ & $\begin{array}{l}5 \% \text { Critical } \\
\text { Value }\end{array}$ & $\begin{array}{c}1 \% \\
\text { Critical } \\
\text { Value }\end{array}$ \\
\hline \multirow{2}{*}{$\begin{array}{c}\text { India - } \\
\text { USA }\end{array}$} & & 0.1218 & 5.094265 & 15.49471 & 19.93711 \\
\hline & At most 1 & .0001 & 0.153994 & 3.841466 & 6.634897 \\
\hline \multirow{2}{*}{$\begin{array}{c}\text { India- } \\
\text { UK }\end{array}$} & None $^{*}$ & 0.112464 & 27.981848 & 15.49471 & 19.93711 \\
\hline & At most 1 & 0.000341 & 0.115027 & 3.841466 & 6.634897 \\
\hline \multirow{2}{*}{$\begin{array}{l}\text { India- } \\
\text { Japan }\end{array}$} & None $^{*}$ & 0.12881 & 23.110794 & 15.49471 & 19.93711 \\
\hline & At most 1 & 0.000260 & 0.708404 & 3.841466 & 6.634897 \\
\hline
\end{tabular}

The test for co-integration between Indian and US stock market show rejection for the null hypothesis of no cointegrating relationship between the two stock markets since the test (trace) statistic of 25.09 is greater than the critical value for both 5 and 1 percent of 15.49 and 19.93 respectively. Moving on to test the null of at most 1 cointegrating vectors, the trace statistics is now well below the 5 percent and 1 percent critical values suggesting that the null should not be rejected. It shows that there exists at most one co-integrating relationship between US and Indian stock market. In simple words, the US and Indian stock market are co-integrated and hence, long-term equilibrium relationship between the Indian and US is present. For UK and Indian stock market the null hypothesis of no co-integration between the UK and Indian stock market is rejected as the trace statistics is again larger than the critical values at both 5 and 1 percent significance level. The next null hypothesis of at most 1 cointegrating relationship is accepted as the trace statistic is now lower than the critical values. Hence, the results reveal that the Indian stock market returns and the UK stock market returns are cointegrated.

Similar results have been achieved for Japanese stock markets. The Nikkei 225 index returns and Nifty 50 index returns are found to be co-integrated. Hence, it is found that the daily return series of Indian stock market is cointegrated with US, UK and Japanese stock market returns. In order words, 
the return and hence volatility of Indian stock market is associated with global markets. It reveals that financial integration of Indian stock market with global markets is present. As the Indian stock market return is found to have long-term relationship with the global financial markets, further examination of the direction and causality of the relationship is required.

Table III presents the output of Granger's causality test to examine the causal relationship between Indian and foreign stock market. The causality test has been undertaken using three lags, which are 2, 5, and 10. Panel A presents the results for S\&P 500 and Nifty 50 daily returns. The null hypothesis of India does not Granger causes USA is accepted for all the three lags as revealed by the insignificant prob value. However, the null hypothesis of USA does not Granger causes India is rejected for all the three lags. Hence, the results reveal that Indian stock market has no effect on US market while US stock market has significant effect on Indian stock market. The effect of US stock market is seen in India upto 10 days. Hence, there is volatility transmission from US stock market to India. The F-statistic value is highest for lag 2 as compared to lag 5 and lag 10, it implies that the recent volatility in US has higher impact on volatility of Indian stock market.

\section{Table 3}

\section{Granger's Causality Test Results}

\begin{tabular}{|l|c|c|c|c|c|}
\hline \multicolumn{7}{|c|}{ Null Hypothesis } & Lag & Observation & F-Statistics & Prob \\
\hline India does not Granger cause USA & 2 & 2728 & 2.11337 & 0.1210 \\
\hline USA does not Granger cause India & & & 90.7051 & 0.00001 \\
\hline India does not Granger Cause USA & 5 & 2725 & 1.4454 & 0.3344 \\
\hline USA does not Granger cause India & & & 39.0928 & 0.00000 \\
\hline India does not Granger cause USA & 10 & 2720 & 1.07081 & 0.3811 \\
\hline USA does not Granger cause India & & & 22.4843 & 0.0000 \\
\hline \multicolumn{7}{|c|}{ Panel B: India-UK } \\
\hline India does not Granger cause UK & 2 & 2728 & 5.12179 & 0.0060 \\
\hline UK does not Granger cause India & & 25.5302 & 0.00000 \\
\hline
\end{tabular}


Volatility Spillover Effect

\begin{tabular}{|l|c|c|c|c|} 
India does not Granger cause UK & 5 & 2725 & 3.03155 & 0.0098 \\
\hline UK does not Granger cause India & & & 13.0296 & 0.00000 \\
\hline India does not Granger cause UK & 10 & 2720 & 1.68944 & 0.0774 \\
\hline UK does not Granger cause India & & & 8.38666 & 0.0000 \\
\hline \multicolumn{7}{|c|}{ Panel C: India- Japan } \\
\hline India does not Granger cause Japan & 2 & 2728 & 66.7634 & 0.0000 \\
\hline Japan does not Granger cause India & & & 0.54803 & 0.5782 \\
\hline India does not Granger cause Japan & 5 & 2725 & 26.6954 & 0.0000 \\
\hline Japan does not Granger cause India & & & 0.67939 & 0.6391 \\
\hline India does not Granger cause Japan & 10 & 2720 & 14.1678 & 0.00000 \\
\hline Japan does not Granger cause India & & & 2.13053 & 0.1904 \\
\hline
\end{tabular}

Similarly, Panel B shows the results of Granger's causality test between stock market returns of Indian and UK. The null hypothesis of India doesn't Granger cause UK stock market is rejected for all three lags (i.e 2, 5 and 10 days). Hence, the results reveal that volatility in Indian stock market effects volatility of UK stock markets. Moreover, the null hypothesis of UK stock market returns doesn't Granger cause Indian stock market return is also rejected for all the three lags. Hence, it is found that the UK stock market volatility has impact on Indian stock market volatility. The results show that two way or bi-directional causality exists between Indian and UK stock market as both the null hypotheses India does not Granger cause UK and UK does not Granger cause India are rejected for all lags. Hence, volatility in UK stock market affects Indian markets and vice-versa. Moreover, the Fstatistics is the largest for lag 2 which indicates recent volatility has more effect on other market.

Finally, the Granger's causality test results for India-Japan presented in Panel $C$ show that Indian stock market causes Japan but Japanese stock market does not cause India. The null hypothesis of Indian stock market return doesn't Granger cause Japanese stock market return is rejected for all the three lags which reveals that volatility in Indian stock market affects volatility in Japanese stock market. However, the null hypothesis that Japanese stock market returns doesn't Granger cause Indian stock market 
returns is accepted for all the three lags. The results show that there is no impact of Japanese stock market volatility in India. In other words, volatility transmission from Japanese stock market to Indian stock market doesn't take place. Combining the results, it is seen that there is uni-directional volatility transmission or spillover between Indian and Japanese stock market. The Japanese stock market volatility is affected by Indian stock market volatility while Indian stock market volatility is not affected by Japanese stock market volatility. Overall, the results reveal that volatility in Indian stock market is affected by volatility of US and UK stock market.

Table IV presents the output of Autoregressive Distributed Lag (ARDL) model to further examine the volatility spillover effect in Indian stock market. The ARDL model regresses Nifty 50 returns on its own lagged values and lagged value of the explanatory variables which are in this case the foreign market return (FMR). The first model shows the output of ARDL model with Nifty 50 return dependent and lagged values (from lag 1 to 5) of Nifty fifty and foreign market return (USA) as explanatory variables. The beta coefficients associated with AR (-1), AR(-2), FMR(-1), FMR (-2) and FMR (-3) are significant. The results show that current nifty return is affected by its past 2 lags and past three days lags of the S \& P 500. Hence, volatility in Indian stock market is influenced by it recent past (two days) volatility and recent volatility of US markets (upto 3 days). The beta coefficients associated with FMR $(-4)$, and FMR $(-5)$ are found to be insignificant. It shows that volatility transmission from US market to India takes place fast. US volatility of more than three days doesn't impact Indian stock market volatility. The magnitude of the beta coefficients for the three significant lags of the foreign stock market (FMR) shows that FMR(-1) has the highest beta coefficient followed by FMR (-2). It shows that the recent volatility in US market has the largest influence in the volatility of Indian stock market.

\section{Table 4}

Output of Autoregressive Distributed Lag Model

\begin{tabular}{|l|c|c|c|c|}
\hline Dependent & Nifty 50 & Nifty 50 & Nifty 50 & Nikkei225 \\
\hline FMR & S\&P500 & FTSE100 & Nikkei225 & Nifty50 \\
(Exogenous) & (USA) & (UK) & (Japan) & (India) \\
\hline
\end{tabular}


Volatility Spillover Effect

\begin{tabular}{|c|c|c|c|c|}
\hline C & $\begin{array}{l}0.047745^{*} \\
(0.02831)\end{array}$ & $\begin{array}{l}0.054604^{*} \\
(0.02898)\end{array}$ & $\begin{array}{c}0.051479^{*} \\
(0.0293)\end{array}$ & $\begin{array}{c}0.007869 \\
(0.028897)\end{array}$ \\
\hline AR $(-1)$ & $\begin{array}{c}-0.052092^{* *} \\
(0.02043)\end{array}$ & $\begin{array}{c}-0.01408 \\
(0.021509)\end{array}$ & $\begin{array}{c}0.056915^{* * *} \\
(0.020627)\end{array}$ & $\begin{array}{l}-0.0888^{* * *} \\
(0.020633)\end{array}$ \\
\hline$A R(-2)$ & $\begin{array}{c}-0.071922^{* * *} \\
(0.0204)\end{array}$ & $\begin{array}{l}-0.06168^{* * *} \\
(0.021552)\end{array}$ & $\begin{array}{c}-0.020416 \\
(0.021126)\end{array}$ & $\begin{array}{c}-0.0361^{*} \\
(0.020712)\end{array}$ \\
\hline AR $(-3)$ & $\begin{array}{c}-0.032242 \\
(0.0204)\end{array}$ & $\begin{array}{l}-0.04463^{* *} \\
(0.021542)\end{array}$ & $\begin{array}{c}-0.017027 \\
(0.021116)\end{array}$ & $\begin{array}{l}-0.07588^{* * *} \\
(0.020658)\end{array}$ \\
\hline$A R(-4)$ & $\begin{array}{c}-0.016551 \\
(0.0202)\end{array}$ & $\begin{array}{c}-0.0006 \\
(0.021407)\end{array}$ & $\begin{array}{l}-0.018043 \\
(0.021095)\end{array}$ & $\begin{array}{c}0.026483 \\
(0.020712)\end{array}$ \\
\hline$A R(-5)$ & $\begin{array}{c}-0.008724 \\
(0.01936)\end{array}$ & $\begin{array}{l}-0.02185 \\
(0.02107)\end{array}$ & $\begin{array}{l}-0.008837 \\
(0.021074)\end{array}$ & $\begin{array}{c}-0.03299 \\
(0.020248)\end{array}$ \\
\hline $\operatorname{FMR}(-1)$ & $\begin{array}{l}0.316383^{* * *} \\
(0.023791)\end{array}$ & $\begin{array}{c}0.191594^{* * *} \\
(0.02682)\end{array}$ & $\begin{array}{l}0.015165 \\
(0.02092)\end{array}$ & $\begin{array}{l}0.234161^{* * *} \\
(0.020343)\end{array}$ \\
\hline $\operatorname{FMR}(-2)$ & $\begin{array}{c}0.170222^{* * *} \\
(0.025157)\end{array}$ & $\begin{array}{c}0.089895^{* * *} \\
(0.027266)\end{array}$ & $\begin{array}{c}-0.013896 \\
(0.021)\end{array}$ & $\begin{array}{c}0.013267 \\
(0.020836)\end{array}$ \\
\hline $\operatorname{FMR}(-3)$ & $\begin{array}{c}0.095458^{* * *} \\
(0.025483)\end{array}$ & $\begin{array}{l}0.095586^{* * *} \\
(0.027537)\end{array}$ & $\begin{array}{c}0.010029 \\
(0.020946)\end{array}$ & $\begin{array}{c}0.021328 \\
(0.020826) \\
\end{array}$ \\
\hline FMR (-4) & $\begin{array}{c}0.029531 \\
(0.025381)\end{array}$ & $\begin{array}{c}-0.02399 \\
(0.027332)\end{array}$ & $\begin{array}{c}0.007341 \\
(0.021)\end{array}$ & $\begin{array}{c}0.007235 \\
(0.020806)\end{array}$ \\
\hline FMR $(-5)$ & $\begin{array}{c}-0.008104 \\
(0.024603)\end{array}$ & $\begin{array}{c}0.010344 \\
(0.027103) \\
\end{array}$ & $\begin{array}{r}-0.029505 \\
(0.02053) \\
\end{array}$ & $\begin{array}{c}0.017817 \\
(0.020784) \\
\end{array}$ \\
\hline F-Statistics & $21.0495^{* * *}$ & $17.95058^{* * *}$ & $13.743583^{* * *}$ & $15.50255^{* * *}$ \\
\hline DW & 2.001189 & 2.002509 & 1.998593 & 2.001647 \\
\hline No of Obs. & 2725 & 2725 & 2725 & 2725 \\
\hline
\end{tabular}

${ }^{*},{ }^{* *}$, and ${ }^{* * *}$ means that the coefficient is significant at $10 \%, 5 \%$, and $1 \%$ level of significance respectively. The values in the parentheses are standard errors.

The second model shows the effect of UK stock market on India. The results are similar to that of US markets and reveal that volatility in UK market affect Nifty 50 volatility. The beta coefficients associated with FMR (-1), FMR $(-2)$ and FMR (-3) are found to be significant and positive. Moreover, the 
magnitude of the beta coefficient is largest for lag 1 followed by lag 2 . It depicts that the volatility in UK stock market up to past three days effects volatility of Indian stock market. Additionally, the recent day volatility has higher impact as compared to higher lag days. In corroboration to above results, it is found that the volatility transmission from UK to Indian stock market is also short. Only the past three days volatility in UK market spills over to India as shown by significant coefficients of FMR for three lags only. The third model shows that Japanese market volatility doesn't have any impact on volatility of Indian market as all the beta coefficients associated with FMR from lag 1 to 5 are found to be insignificant. The Granger's causality test revealed that Indian stock market causes Japanese market. So, the fourth model uses Nikkei 225 index returns as dependent variable in the ARDL model. In corroboration to the results of Granger's causality, the Indian stock market volatility is found to affect Japanese stock market volatility. However, only the coefficient of lag 1 is found to be significant. It indicates that volatility transmission from Indian to Japanese stock market is quick and lasts for only a single day.

\section{Conclusions}

The Indian stock market return is found to have long term relationship with market returns of US, UK and Japanese stock markets. In order words, the return and hence volatility of Indian stock market is associated with global markets. It reveals that Indian stock market is getting integrated with global financial markets. The results provide empirical evidence for volatility transmission or volatility spillover in the Indian stock market from global markets. There exists inbound volatility transmission from US market to Indian stock market. The Indian and UK stock market have bi-directional volatility transmission. However, there exists presence of only outbound volatility transmission from Indian stock market to Japanese stock market. The volatility transmission from global markets to India takes place fast with the spillover effect existing for up to three days only. Moreover, the results show that the past one day's volatility in foreign market has the greatest influence in the volatility of Indian stock market. As foreign portfolio 
investment and volatility transmission from global markets are found to have major impact on volatility in the Indian stock market, policymakers should initiate efforts and devise policies to reduce the adverse impact of foreign portfolio investment while maintaining balance for the promotion of foreign portfolio investment in India and facilitating further financial integration of the Indian stock market with global markets.

\section{References}

Ackert, L., \& Deaver, R. (2010). Behavioral finance: Psychology, decisionmaking, and markets. Mason, $\mathrm{OH}$ : South-Western Cenage Learning. New York: McGraw-Hill.

Aggarwal, R., Inclan, C., \& Leal, R. (1999). Volatility in emerging markets, Journal of Financial and Quantitative Analysis, 34(1), 33-55.

Azzam, H. (2010). Volatility spillover effects on emerging stock markets. Journal of Economic Studies, 39(2), 178-211.

Badhani K.N. (2009). Response asymmetry in return and volatility spillover from the US to Indian stock market. The IUP Journal of Applied Finance, 15, 22-45.

Bhar, R., \& Nikolova, B. (2007). Analysis of mean and volatility spillovers using BRIC countries, regional and world equity index returns. Journal of Economic Integration, 369-381.

Caprio, G. (2012). The evidence and impact of financial globalization. San Diego, CA: Elsevier Inc.

Dickey, D. A., Jansen, D. W., \& Thornton, D. L. (1991). A Primer on Cointegration with an Application to Money and Income. Federal Reserve Bank of St. Louis Review, 73(2), 58-78.

Engle, R. F., \& Granger, C. W. (1987). Co-integration and error correction: representation, estimation, and testing. Econometrica: journal of the Econometric Society, 251-276.

Harrison, B., \& Moore, W. (2009). Spillover effects from London and Frankfurt to Central and Eastern European stock markets. Applied Financial Economics, 19 (18), 1509-1521. 
Karmakar, M. (2007). Asymmetric volatility and risk-return relationship in the Indian stock market. South Asia Economic Journal, 8(1), 99-116.

Kumar, K., \& Mukhopadyay, S. (2002). Equity market interlinkages: Transmission of volatility: A case of US and India. NSE Research Initiative Paper No. 16.

Kumar, S. (2012). A first look at the properties of India's volatility index. International Journal of Emerging Markets, 7(2), 160-176.

Lee, S. J. (2009). Volatility spillover effects among six Asian countries. Applied Economics Letters, 16(5), 501-508.

Li, Y., \& Giles, D. E. (2013). Modeling volatility spillover effects between developed stock markets and Asian emerging stock markets. Paper presented at Society for Computational Economics (CEF) Conference. Vancouver, Canada.

Mukherjee, K.N., \& Mishra, R. K. (2005). Stock market inter-linkages: A study of Indian and world equity markets. Indian Journal of Commerce, 58 (1), $17-42$.

$\mathrm{Ng}, \mathrm{A}$. (2000). Volatility Spillover Effects from Japan and the US to the Pacific-Basin. Journal of International Money and Finance, 19 (2), 207-233.

Rao, B. S. R., \& Naik, U. (1990). Inter-relatedness of stock markets: Spectral investigation of USA, Japanese and Indian Markets. Artha Vignana, 32 (3), 309-321.

Thenmozhi, M., \& Chandra, A. (2013). India volatiltiy (India VIX) and risk management in Indian stock market, NSE Working Paper.

Wang, G. J. (2007). Essays on option-implied volatility (Doctoral dissertation, Syracuse University).

Wang, M. C., \& Shih, F. M. (2010). Volatility spillover: Dynamic regional and world effects. European Journal of Finance and Banking Research, 3 (3), 29-38.

Yang, J., Yang, Z., \& Zhou. Y. (2012). Intraday price discovery and volatility transmission in stock index and stock index futures markets: Evidence from China. Journal of Futures Markets, 32, 99-121. 